\title{
Interoperable Process: Efficient Systems in New Constructive and Product Performances
}

\author{
Consiglia Mocerino \\ Already contract professor in the Faculty of Architecture, Sapienza University of Rome-Miur, Rome, Italy
}

\begin{abstract}
In the construction sector, which is one of the major goals of the new economy, the company is aiming at a new constructive practice and upgrading of the built, using ICT (information and communications technology) technologies. So the focus is on new operating and organizational models of sustainable building processes in the architecture, engineering and construction sectors, which are based on three-dimensional models of digital technology BIM (building information modeling). It is intended as a human activity that improves building workflows and, through software and IFACs (industry foundation classes), manages flexibility, coordinates and optimizes operational choices on time, economic, and environmental sustainability parameters. The goal is a new interoperable building process that involves designers, contractors and businesses from programming to lifecycle building and maintenance through the integrated project delivery of the building. Dynamic architectures, interactive with efficient technological and constructive systems, are integrated with innovative products of complex nature and bi-directional performance, engineered, with energy storage and renewable resources. The methodologies are based, above all, on the adoption of BIM technologies with the digital project manager and the use of robotic technological tools. Digitization is applied for the design and construction of architectural and infrastructure artifacts, in interaction with intelligent, adaptive, nanotechnical and user-friendly materials and climate. The results are aimed at efficient buildings with user comfort and safety, accuracy, and risk monitoring with remote monitoring, highlighting VDC (visual design construction) in CID (computational intelligent design).
\end{abstract}

Key words: Construction, technology, digital system, process, interoperability, concrete, adaptive, design, sustainability.

\section{Introduction}

The construction industry, with the evolution of ICT (information and communications technology) [1] aims at a new constructive practice and redevelopment. They are primarily aimed at the architectural and technological quality of user welfare, through an interdisciplinary design and product process that highlights efficient and eco-sustainable building systems, made in the software environment by the most advanced and intelligent components. For this reason, three-dimensional virtual models are developed, according to the BIM (building information modeling) methodology, managed by the digital project manager, as tools that can handle all stages of a building's life cycle.

Corresponding author: Consiglia Mocerino, Arch. Ph.D., research fields: technological innovation, sustainable and smart systems, energy and environmental requalification of buildings. E-mail: 1.mocerino12@gmail.com.
So new constructions come together in the broad spectrum of information technologies, converging into the emerging energy of a so-called "new economic paradigm for the 21 st century", which, according to Jeremy Rifkin, is the third economic revolution [2].

In fact, only the construction sector is responsible for $40 \%$ of the air pollution, so they need emerging local and global management with upgrading built and ex-constructions.

For this reason, in the new economy, through the digitization policies of the EC, national and global, the aim is to improve the quality of life, urban and territorial spaces, environmental and cultural sustainability. Therefore, the adoption of different systems and products, the performance of every type of building, residential, commercial, office, industrial, etc., must meet the needs and demands of new real estate markets. This involves the sprint of the digital technology BIM of IPDB (integrated project database) 
or integrated project archive, in new architectural performances, especially for public, commercial, and tertiary buildings. In fact, with the approval of the new Code of Procurement (D.Lgs 50/2016), art.23, the standard for building modeling and infrastructure-BIM, UNI 11337: 2017, follows the English ones BS (British Standard) and PAS (Publically Available Specification), as integrated management of public procurement. From the CEN (Committee European Normalization) group, for the first time, the development levels that provide information sources for the different design teams are established, LOD $^{2}$ (Levels of Development, according to Americans, Level of Definition, according to English), are specific for the cycle of life, the recovery and the restoration, also in consideration of the vast Italian patrimony of cultural heritage. Also the figures are involved in the digital management of different processes, such as BIM manager, BIM coordinator, BIM modeler.

This evolutionary methodology implements an efficient performance system in the building, helping, enhancing and improving the workflow. It is through the interoperability of the different building process figures with lifecycle, from programming, realization, management and maintenance. In fact, between the procurement procedures, integrated building design or IPD (integrated project delivery) with application of IT [3] and BIM method, on parametric evolutionary modeling, becomes a competitive prerequisite for the efficiency of the industry of the AEC (architecture, engineering and construction). IPDs are applied by different methods, according to the regulations of the different states, but the common component is that of the collaboration of the clients (or their consultants), designers and companies at all stages of the design, construction and delivery process. Through these procedures, besides the conformity of the project, according to the requirements of the client, the efficiency of the reduction of the times and costs is verified. In addition, with the application, management of a BIM, IFCs (industry foundation classes), an open format of information that includes, beyond the technological system, physical quantities such as masses, transmittances, etc., even times of the various stages of processing, the quantities with relative construction costs. In fact, the standard (ISO 16739) exchanges and shares data without conversion.

For the sustainability and improvement of the quality of public wealth, the EU BIM Task Group [4] indicates, at the European network level, guidelines in the BIM Handbook for Stakeholders in the EC. Also, we are using the CDE, or ACDat in the data environment, then, methodologies of efficient digital systems synchronous with the requirements of the new design practice, in terms of efficiency and sustainability, with the adoption of innovative systems, components and products and devices that interfere with distributed intelligence and renewable energy, especially in tall buildings where there is considerable use of energy, cloud manufacturing application and pay-by-use mode, and database control capabilities, with increased resource values.

So we are witnessing an evolutionary transformation in the construction, with the application of new technologies, adaptive materials and robot use [5]. The latter can realize the whole construction, from excavation drilling, foundations to roofs. In addition, through three-dimensional modeling simulations, robots create complex and efficient dynamic shapes with timing benefits, enhancing safety, accuracy, reducing the risk of accidents on construction sites, and monitoring remotely. These new performances become the drivers of a sustainable process and platform of BIM technology according to the 2014/24 "European Union Public Procurement Directive". This is why the use of certified materials is in line with the Italian NTC (Technical Standards for Construction), in line with European Commission regulations. Especially for the adoption of structural, eco-sustainable, adaptive, smart materials with high mechanical 


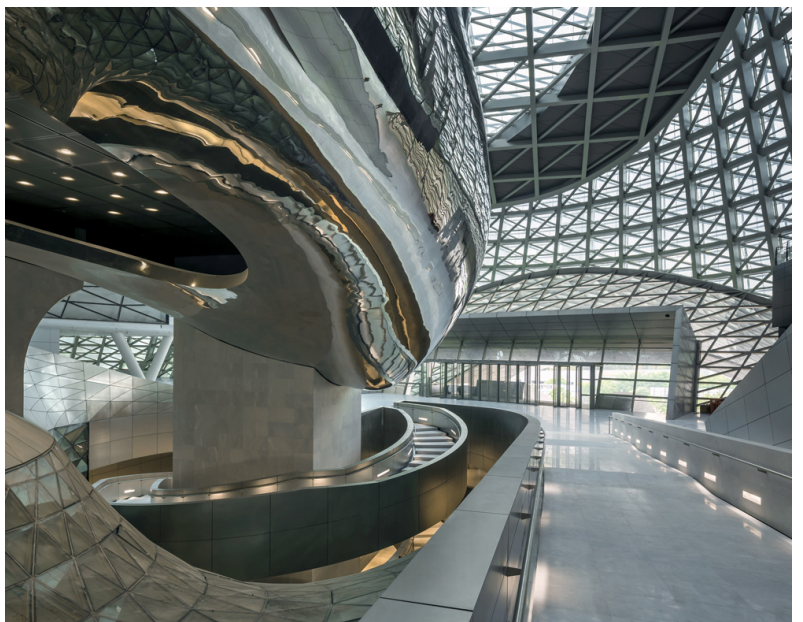

Fig. 1 MOCAPE, Coop Himmelb (l) au di Wolf Dr. Prix. Interior, Museum of Contemporary Art (MOCA) and Planning Exhibition (PE) 2016, Shenzhen, China.

Source: Ref. [6].

security, durability and versatility (concrete, reinforced fibers, X-lam wood, glass, natural stone, etc.), with $\mathrm{CE}$ marking of the EU Regulation 305/2011. In architecture of the cultural center (Fig. 1) MOCAPE of 2016, is highlighted a coating of natural stone with solar control glass and the use of renewable energy systems, from geothermal and solar sources. There are complex forms, especially in the hall, in which steel plates cut and bent to the laser are applied, secured, seamless, and grasped by robots [7].

\section{The Interoperable Construction Process}

\subsection{Efficient Practices}

The goal of a new architecture performance focuses on low environmental impact systems that interact with user needs through an interoperable process of operational and organizational models that combine technical, social and legal skills.

In this new design and product process, the parametric modeling application BIM is understood as a human and non-software activity, which, with VDC (visual design construction), highlights the potential for eliminating uncertainties in the execution process. It is implemented by innovations, such as the application of radio frequency identification (RFID) technology, through codes, constructive components detection, design and construction methods.

Their greater efficiency is achieved in smart buildings, tall buildings, offices, commercial buildings, hospitals, and tertiary. It goes to computer control, from man-controlled devices, with greater control of environmental pollution and waste recycling, from the aerospace field, to building components, dynamic envelopes and computerized machines (digital fabrication, etc.). Software, sustainable design

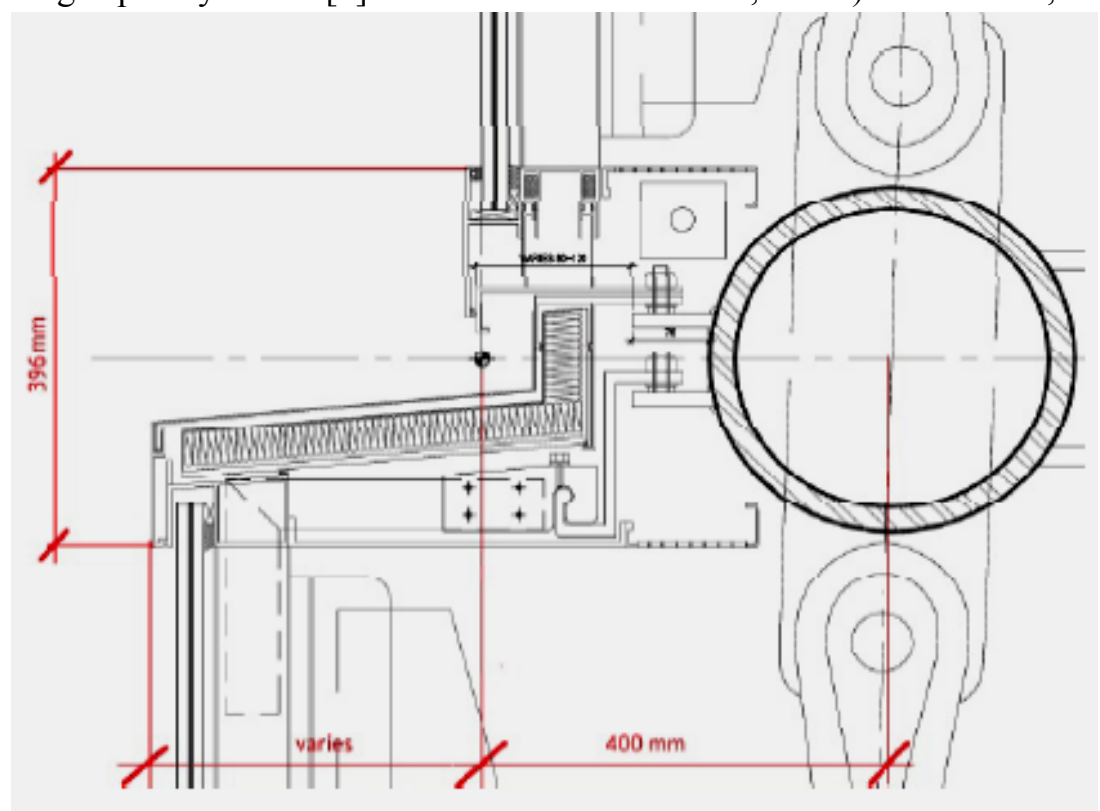

Fig. 2 Shanghai tower, double skin, detail curtain wall system, "A".

Source: Ref. [8]. 
calculation of double/triple glass facades (Fig. 2) with continuous envelopes, with strategies for parameters and technological efficiency including the reducing energy consumption up to $21 \%$, etc., so do the interoperability and integration of dynamic building elements with the computational designer, efficient and material systems with flexible and coordinated management for the air conditioning, distribution of energy from renewable sources, including services with secure supply systems, integrated with RBEs (responsive building elements) technology. Furthermore, the foundation structures, the closure systems, the internal partitions with roofs and floor coverings, the partition walls, the floors, and so on, they integrate with all building system systems, especially with the HVAC (heating, ventilating and air conditioning) system. They are aimed to reduce the energy consumption, with capacity for accumulation and transmission of heat, light, air, water and dynamism to the building. The same ventilated and continuous facades, energy systems (with storage capacity of building materials) and active systems, massive nanostructured materials, PCM (phase change materials), TM (thermal mass), etc., increase the efficiency of the building. Finally, AIF (advanced integrated facade) and intelligent skins for high performance envelopes with the F.E.M. (finite element method) to enhance thermal, mechanical, energy, and aesthetic performance, also in response to climate change.

Then BIM technology, as a management tool control, also during the management, works with optimization of the different choices of site activities. Three-dimensional model, with application of sustainable materials, nanomaterials, nanostructured (nanowire, nanotubes, etc.) and engineered ECC (engineered cementitious concrete) in efficient systems.

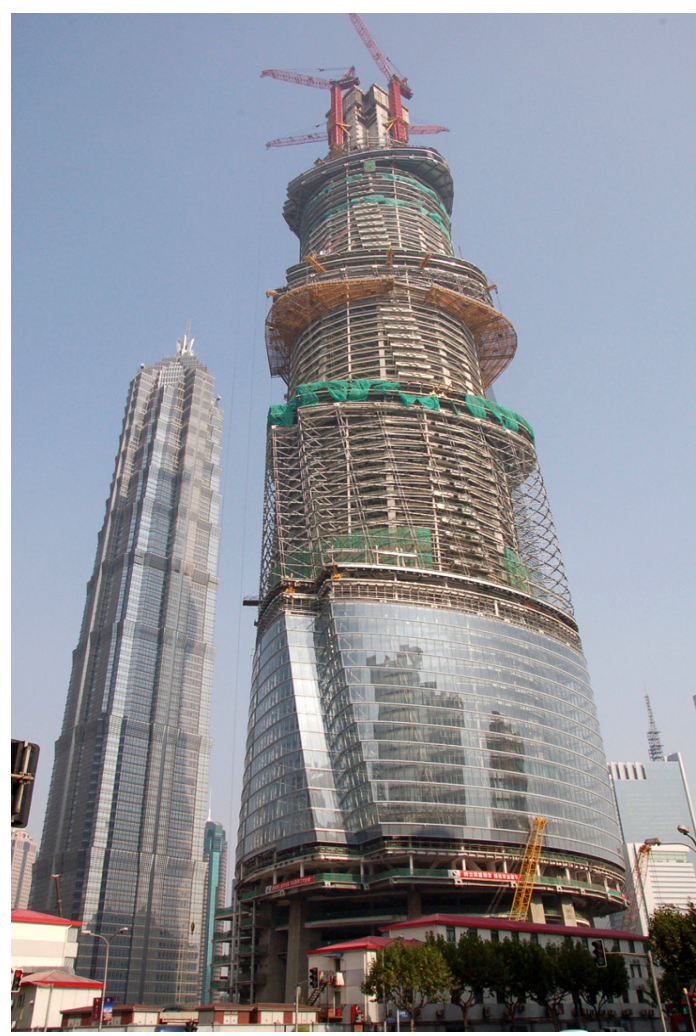

Fig. 3 Shanghai tower of Gensler architects, high 632 m, double skin curtain wall, green technologies with about 200 wind turbines (the highest in the world), top of the tower, which produce about $10 \%$ of total electricity.

Source: Ref. [9]. 
Focusing on the integration of the production of electricity from solar thermal, geothermal, wind, etc. in the different HVAC systems, for this reason, the use of thermodynamic systems, such as high performance PdC (heat pumps) and COP (coefficient of performance) $>5$, is a performance-inverter coefficient especially fueled by air. They are integrated with innovative photovoltaic solar systems (with PV systems emptying systems for the risk of winter frost or overheating). They develop stand-alone, off-grid PV systems that are able to supply electricity in difficult access areas to the national network, as in rural, mountain and third world countries. The trend is toward the storage systems of energy produced, especially for particular plant systems, and the challenge lies in renewable energies, as systems help to reduce electricity supply from the national distribution network during winter and with little solar power (Fig. 3).

\subsection{Highly Constructive and Technological Performance}

Energy efficiency and plant integrates constructive efficiency with CID (computational intelligent design), through new design process models, in synergy with energy needs and renewable energy use. BIM [10] modeling, coupled with structural, technological, product, and plant design requirements, optimizes the dynamism of shapes in operational models, on automated IT bases, in connection with IoT and smart metering. In fact, the designer's models, along with control algorithms, which result in device programming, interact with the efficiency of BIM-based modeling, innovating systems with building digitization. Natural ventilation systems with ventilated facades and assembled eco-sustainable materials, such as the new fiber-reinforced photocatalytic cements with high performance UHPC (ultra-high performance concrete), etc. In fact, they show excellent compression resistance (greater than 100-120 MPa), good traction resistance (15 MPa), flexion, good ductility $(0.4 \%)$ and resilience. These intelligent and adaptive materials collaborate on a constructive synthesis, indicating the performance of RBEs, which optimize energy consumption without resorting to particular plant systems. In fact, in the building's technological system, with the integration of passive systems to active ones and the use of renewable sources, special horizontal partitions of the supporting structure, generally with prefabrication systems, form two-tier structural and structural functions. In particular, for HVAC lighting, commercial and public buildings, the trend is to exploit the principle of activating the mass of building, to heat or cool environments with passive systems that exploit, in particular, RBE energy storage performance, with active energy systems.

For example, the ConcretCool system represents the integration of a ventilation system with a radiant system, inserted into reinforced concrete floors, and the activation of the thermal mass, defined as accumulation capacity, thermal energy, building components. The ability of the mass to accumulate and transmit energy, limiting fluctuations from the temperature of the thermal source and "free" inputs (internal endogenous loads to the building and solar irradiation), optimizes the energy performance of the building with comfort and energy-efficient free-cooling. In fact, the ConcretCool radiant system consists of a series of serpentines (metal tubes varying from $\varnothing 60$ to $\varnothing 80$, circular section and provided with internal flanges to increase heat transmission) laid along the reinforcement of the soles, usually prefabricated, and completed with concrete casting (Fig. 4), with diffusers, even of linear type, on the wall or ceiling (Fig. 5).

In this regard, there is a dual function in the system: the delivery air (about $14{ }^{\circ} \mathrm{C}$ in summer, $10{ }^{\circ} \mathrm{C} / 15^{\circ} \mathrm{C}$ in winter, heated by heat recuperators) for ventilation through pipes, releases refrigerant energy to the mass of the floor that accumulates and releases, through its radiant surface (slabs), cooling energy (60 and 80 


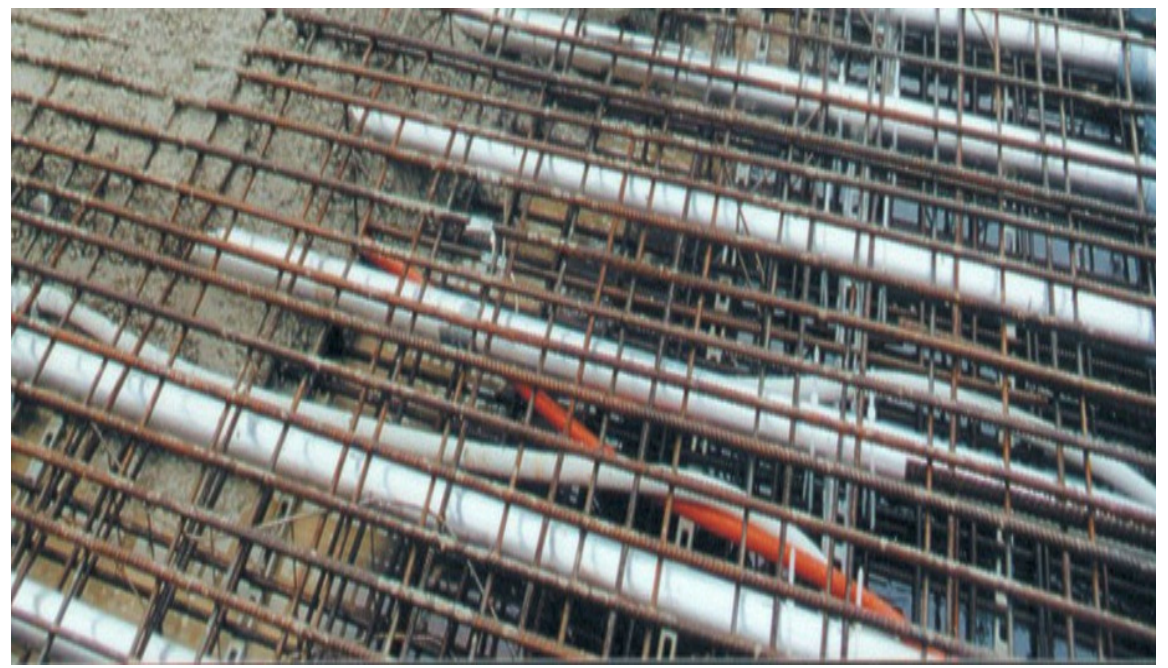

Fig. 4 Tubular systems laid in the reinforcement of the floors with concrete casting. Source: Ref. [11].

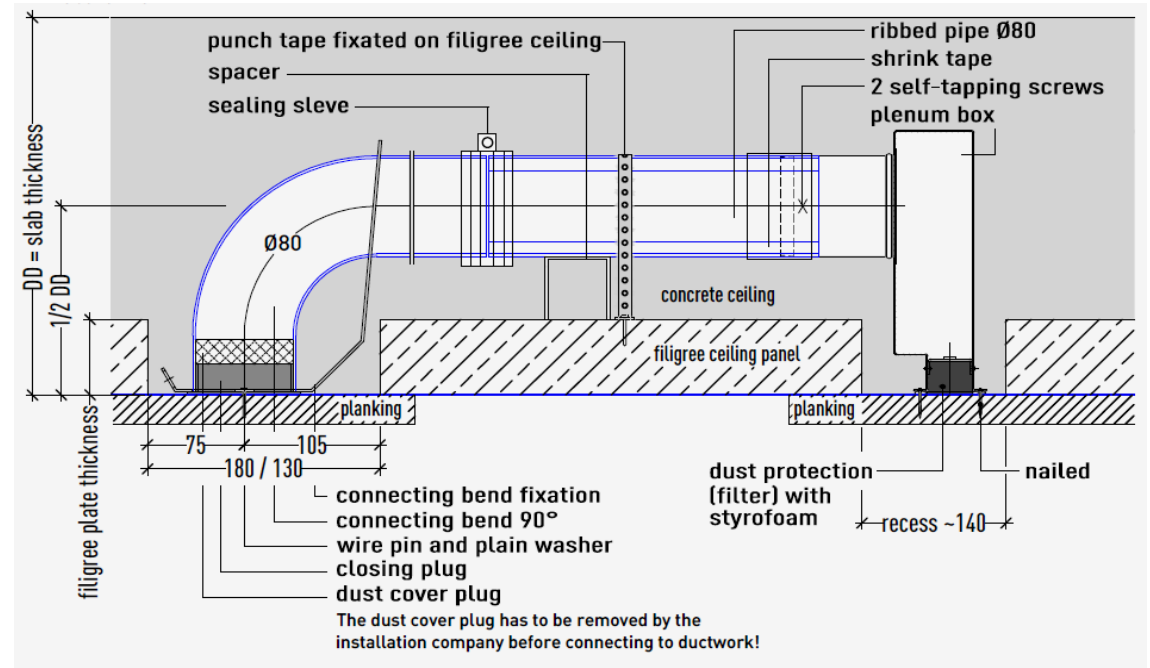

Fig. 5 ConcretCool—cooling coils and linear ceiling diffuser, in concrete.

Source: Ref. [12].

$\mathrm{W} / \mathrm{m}^{2}$ ) with the benefit of cooling the air in the indoor environment free of charge (free cooling), without the use of refrigeration systems. The air, after shedding its cooling energy to the mass, is heated with internal temperatures from $21{ }^{\circ} \mathrm{C}$ to $22{ }^{\circ} \mathrm{C}$, with the possibility of being distributed in the rooms through high-output induction air diffusers and air recovery, with the benefit of reducing primary energy requirements. The systems are distinguished by direct and indirect VAR (variable air volume) and constant CAV (constant air volume) variable volumes with external air inlet (enthalpy external air < enthalpy inner air) in the interior. Instead, the second (indirect) use of a cold thermal (geothermal or air) source, to cool the water in the terminals or in the CTA (air treatment centers). The benefits are of thermal comfort, without cooling and energy saving up to $50 \%$, with free cooling, reduced construction costs, eliminating false ceilings and increased ground floor levels (about 1 per 10) in the building, flexibility with modular distribution of pipes, cooling of outdoor air, without recirculation air, etc. This system differs mainly from the traditional radiant, as it only uses air with optimum outdoor temperature values for temperature, humidity and indoor ventilation control $16^{\circ} \mathrm{C}$.

In buildings, compared to materials with low or 


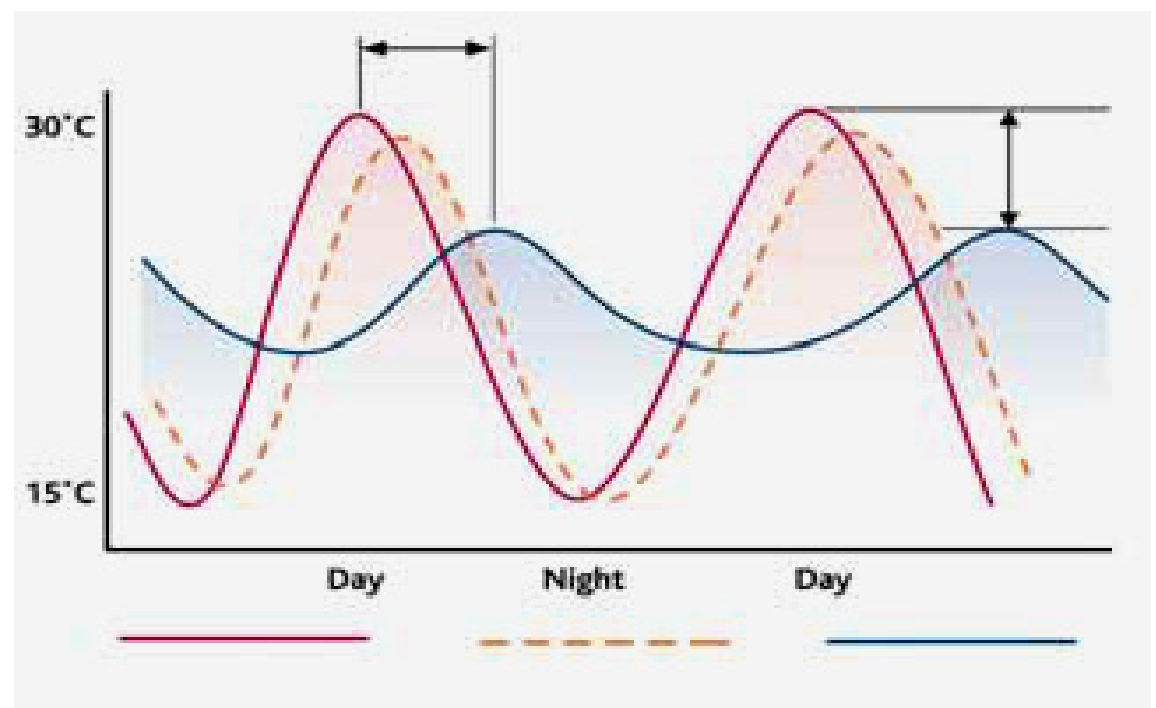

Fig. 6 Indoor temperatures for buildings with high or minimum thermal mass.

Source: Ref. [13].

high thermal mass (Fig. 6), with relative storage capacity, concrete, natural stones and bricks are the most advantageous, having high thermal inertia, directly proportional to the specific heat and thermal mass, and inversely proportional to the difference in internal and external temperature and conductivity. The outside peak temperature is delayed by the mass until hours after, especially for offices, with cooling strategies, overnight with the benefit of free cooling and thermal gain during the day. Therefore, technological quality is highlighted in high performance in the building system with components, materials, and plant systems integrated into a feasibility digitized techno constructive that also improves the complexity of shipyard activities. That is why intelligence efficiency is aimed at new, dynamic, and flexible envelopes, and above all with a "skin" that metabolizes the building with comfort, user comfort, and energy savings. Additionally, remote centralized viewing tools for consumption, alarms, environmental parameters, and building management databases are developed.

To the sensitivity of wireless systems and networks, linked to a big data that collects data from sensors and devices, and then elaborates and improves all the performance of the building, it also connects the dynamism of materials and components of the architectural envelope. In fact, the façade becomes a selective filter that converts, through the use of smart and innovative materials, the capture of solar radiation in thermoelectric energy, from renewable sources, and connected by the wireless chips to the Internet of things, it interfaces with the user. The latter manages all internal and external building systems with use of smart card, which transmits any plant failures and all programming of the environmental, energy and telematic parameters of the building. Also, the experimental facades, such as Windswept (C. Sowera designer), equipped with micro anodized aluminum arrows, interact and form an interactive skin that follows the natural wind direction. Product performance and materials are adapted and modeled with innovative technologies [14]. Thus, efficient systems will satisfy the needs of the technological system [15], of contextualized envelopes, with zero environmental impact, and psycho/socio/cultural needs of users, which ensures, besides the inner well-being of conditioning and heating, also the visual and perceptive. Therefore, solar control, water, air and space adaptability are essential to meet the building's usability requirements, along with the operation of all plant systems based on the setting of parameters. In 
addition, it requires greater insight and research, an appropriate reference model for the behavior of groups of users who, with their movement and their actions, influence systems in the building.

In fact, their position becomes conditioning on the optimization of the project, along with a careful energy audit, which could achieve optimum performance results, energy management and indoor building environments. At the same time, the building, with its energy consumption, interacts with the behavior of the user, influencing physiological, economic and psychological aspects in addition to culture, comfort, safety, security, etc. So methods are analyzed and implemented, integrating user behavioral soft modules, with building energy modeling programs, user presence patterns and their flow with standards and methodologies, etc., as in some research projects including IEA-EBC, Annex 66, then, integrating efficient systems, user actions, materials and components that affect building construction and infrastructure. Indeed, the anti-seismic "flexible bridge" (Fig. 7), under construction in Seattle's industrial district, SoDo, Washington, USA, the world's first pilot project in 2016, is the result of a long search by the WSDOT (Washington State Department of Transportation) and University of Nevada. In this project, the innovative "flexible bridge" technology incorporates two systems, the "memory retaining metal rods" SMA (shape memory alloys)-nickel/titanium, with a "bendable concrete composite", a type of fiber-reinforced concrete based on polyvinyl resins. The advantage is that the anti-seismic bridge resists magnitude 7.5 (Richter scale) telluric shocks, with high flexibility and leaving the verticality of the piles (flexible columns) supporting the bridge beams unchanged.

The prevalent feature of SMA materials, reversible in form, thermoplastic, super elastic, and two ways memory shape effect mode, if cooled, changes the initial shape again. Costs reach almost 90 times more compared to steel and cement. This fiber-reinforced composite based on cement, is started in recent research to improve its flexibility, strength and lightness, such as the new bendable concrete ConFlexPave product at NTU (Hayang Technological University).

This is a type of concrete polymer microfibres (concrete, gravel, sand and water with special synthetic fibers) with a skid resistance, more steel, and a longer lifecycle than traditional cement. It is a sustainable material, also used for road flooring, in very thin and durable prefabricated slabs, requiring less maintenance and quick application. Among the additional products in the construction, even the

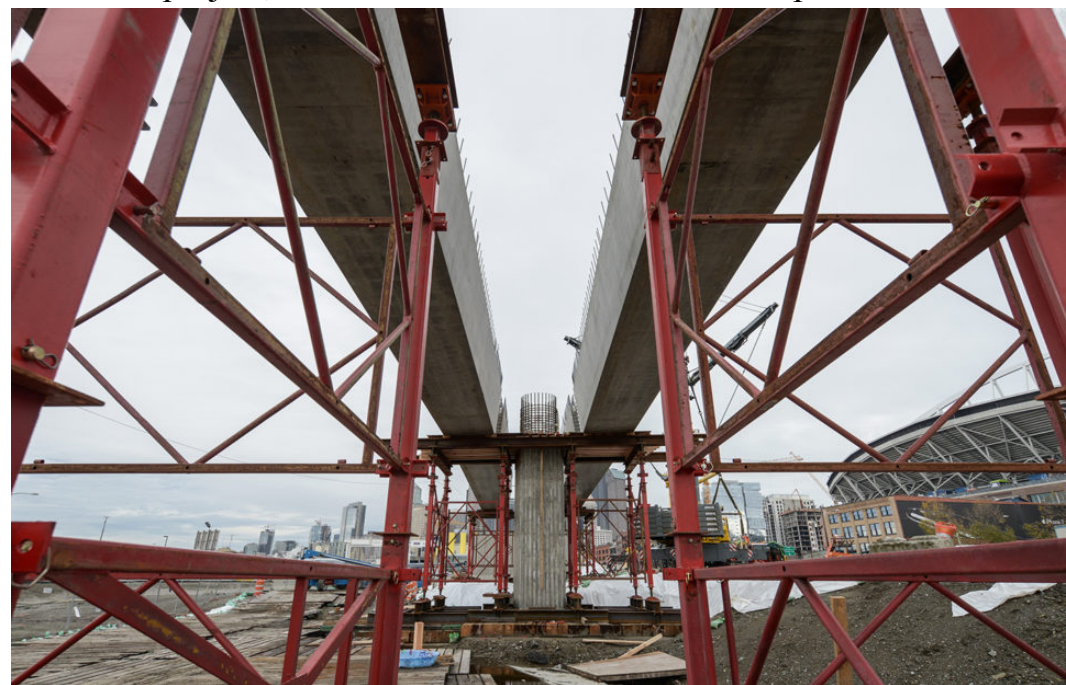

Fig. 7 "Flexible bridge" - the first pilot project in the world, 2016, SoDo, Seattle, Washington, USA. Source: Ref [16]. 
Aerographite, with compression and traction resistance, when compressed, up to $95 \%$, returns to its initial state unaltered. Instead, UMMs (ultralight metallic microlatex), metallic foam, electromagnetic nanotubes, the Boeing Microlatex, represent a quarry metallic nanostructure, ultra-light and formed from 99.9\% air with $0.9 \mathrm{mg} / \mathrm{cc}$ density, 100 times lighter than the XPS (extruded polystyrene foam) and inferior to aerogel. It has a three-dimensional open-air structure, and is also used in space and aeronautics, indicating excellent performance such as acoustic insulation, floating floors, and so on. In the PV industry, however, there are thin film organic cells that are biodegradable and ultra-recyclable plant leaves, photosystem-I (PS-I). While the DSSC (dye sensitized solar cells), nanotechnologies for the production of electricity, based on titanium nanoparticles of $\mathrm{TiO} 2$, are welded to colored and low-cost cells, in third-generation photovoltaic envelopes. The amount of conventional silicon of photovoltaic cells is improved by about $1 \%$, with the use of polymers where nanowire cells are inserted, with energy efficiency. In fact, MEG (carrier multiplication) or multiple generation of excitons in semiconductor nanocrystals has more efficiency in transferring to another electron, the excess energy generated by each photon that hits the cell and in which the electron is generated, like intermediate-band IB materials and solar cells, high performance absorption depending on their geometry, and so on. Also, an amorphous silicon gel, which in the form of swirling varnish or interlayer filling, is transformed into semiconductor for PV modules, between materials that integrate into opaque, lightweight and transparent double or triple glasses solar control. In fact, the KTH Royal Institute of Technology in Stockholm, Sweden, has produced a translucent wood type from which, by extracting lignin, becomes white in color, integrated with the PMMA (polymethylmethacrylate) resin, transmits high performance and is $100 \%$ recyclable, leaving properties unchanged. These give the envelope, the hardness, the ability to vary with different colors, depending on refractive indexes and degree of transparency, high luminous transmission, UV resistance and atmospheric agents. Even the ventilated façade, with a regenerative effect of the entire construction, a dry construction system [17], is a component of the sensitive architectural envelope, especially from the external thermal excursions to the chimney effect generated by the micro ventilation between the façade of the building and the one anchored to it. In this way, the breathability of the main façade is achieved, with the benefit of internal environments and thermo-acoustic well-being. To this end, many sensors are also integrated into the facade modules by operating openings and envelopes, depending on the intensity of the light, heat, and intensity of the sound that via electronic devices are handled by the user remotely.

In the building, it contributes to this efficiency, also the orientation of the large openings, depending on the layout of the interior. Wide geometry windows are usually located in the south, while in the lower north, with high performance shades to the west, to avoid overheating in the afternoon. The design of solar shades affects the dynamism of the transparent envelope, along with the shape, with radiative surfaces of polymeric materials, microforated sheets, smart materials and surface reflection that can vary between 300 and 2,500 $\mathrm{nm}$. In addition, innovative materials of a complex nature and bi-directional performance such as photocatalytic cements, intelligent bricks, biomaterials, networks of chemical sensors, fiber optic networks etc. Integrated with architectural design and interactive architectures [18].

\section{Case Study}

Italy Pavilion-Rho-Pero, Milan Expo S.p.A., 2015-Arch. M. Molè and Arch. S. Tradati, Nemesi \& Partners project in Rome, in collaboration with Proger and BMS Progetti and Prof. Ing. L. De Santoli 
for energy systems [19]. In new high-performance architectures, it occurs the application of efficient systems such as that for the Expo 2015 in Milan, of the Italian Pavilion, whose design includes two buildings, of which the Palazzo Italia and that of Cardo with temporary and removable typology. The area, after the 2015 World Expo, is being subject to urban regeneration, with targets for retraining and functionalize of some works left on the site. For this reason, the Masterplan HT "Human Technopole 2040" by HT was developed, with Expo S.p.A., the support of PriceWaterhouseCopper and R. Berger.

The project is the first Italian pole of "Park of Science, Knowledge and Innovation", (22.00 $\mathrm{m}^{2}-35.00 \mathrm{~m}^{2}$ for HT, 4,000 $\mathrm{m}^{2}$ for green areas), a hub through HP and the campus of University of Milan. There are seven workshops and four facilities, with recovery and reconversion of two pre-existing works, two other ex works, to be carried out, near the Palazzo Italia, which will be the headquarters of the HP district. The Palazzo Italia, 14,400 $\mathrm{m}^{2}$ with basement, six floors on the ground floor and $590 \mathrm{~m}^{2}$ of rooftop panoramic terrace, is distributed on a quadrangular plant, on the side of approximately $57.50 \mathrm{~m}$, divided into four blocks for office space representation to the north, to the auditorium to the south, to meeting/meeting spaces in the east, to the west to exhibition spaces. A dining space is distributed on the fourth floor.

Also, the removable Cardo-12,500 $\mathrm{m}^{2}$, building with two floor planes and terrace with European Union pavilion, is also designed for offices with exhibition, meeting and dining spaces.

\subsection{The Concept}

The architectural work of Palazzo Italia, with an excellent performance and plasticity of shapes, in the context of the fair and in the landscape of the Milan hinterland, highlights a sophisticated white casing, with a distribution layout of efficient constructive and technological systems (Fig. 8 ). Lightness, flexibility and fluidity extend through a conscious spatial and distributive perception, in which the typological quality of interventions and materials is exalted. In the building, there is a tectonic and formal logic, structured on a free plan and sinuous vertical development, highlighting an interaction of complex systems and components of the building system.

The supporting structure in c.a is developed with a method of finite elements, such as shell, and is configured on the ground floor with main vertical land drains concentrated in eight staircase blocks serving the building, with hoists and 12 lifts. The project realized by Italiana Costruzioni Spa, highlights steel systems, in c.a. with large lights and prefabrication, with floor-topped floors (28 cm wide) on metal mesh beams, both exterior and interior, for offices. For the roofs of the auditorium and exhibition halls (south/west), there are solitary predalles $(20 \mathrm{~cm})$ on metal beams that vary from HEA 200 up to HEB 650, and on divisions in c.a. (external side) solidarized and completed casting in cls, with full soles, such as the stairwells and the backsets. Also for the east-north/east meeting spaces, the soles are made of solid soles in c.a. and stand on metallic columns, resting on a plate in a c.a of $120 \mathrm{~cm}$. Instead, a central staircase has been constructed with steel structure and, from the ground floor of the foyer, leads to the first floor. In addition, steel tubes, both internal and external, with metal beams for interior facades, foyer area, and exterior to the north and east, are installed for the exhibition spaces, offices, etc. Innovative technologies are distinguished by BIM and 3D modeling of a low-impact, high-performance, energy-efficient, and sustainability-based architectural project, with LCA (life cycle assessment) products, in the integration of emerging and advanced materials, including glass, steel and cement. In the layout, from the foyer area (the central space of the ground floor similar to an Agorà), sinuous types of vertical and horizontal connections with suspended ramps, walkways and bridges are highlighted. They are 


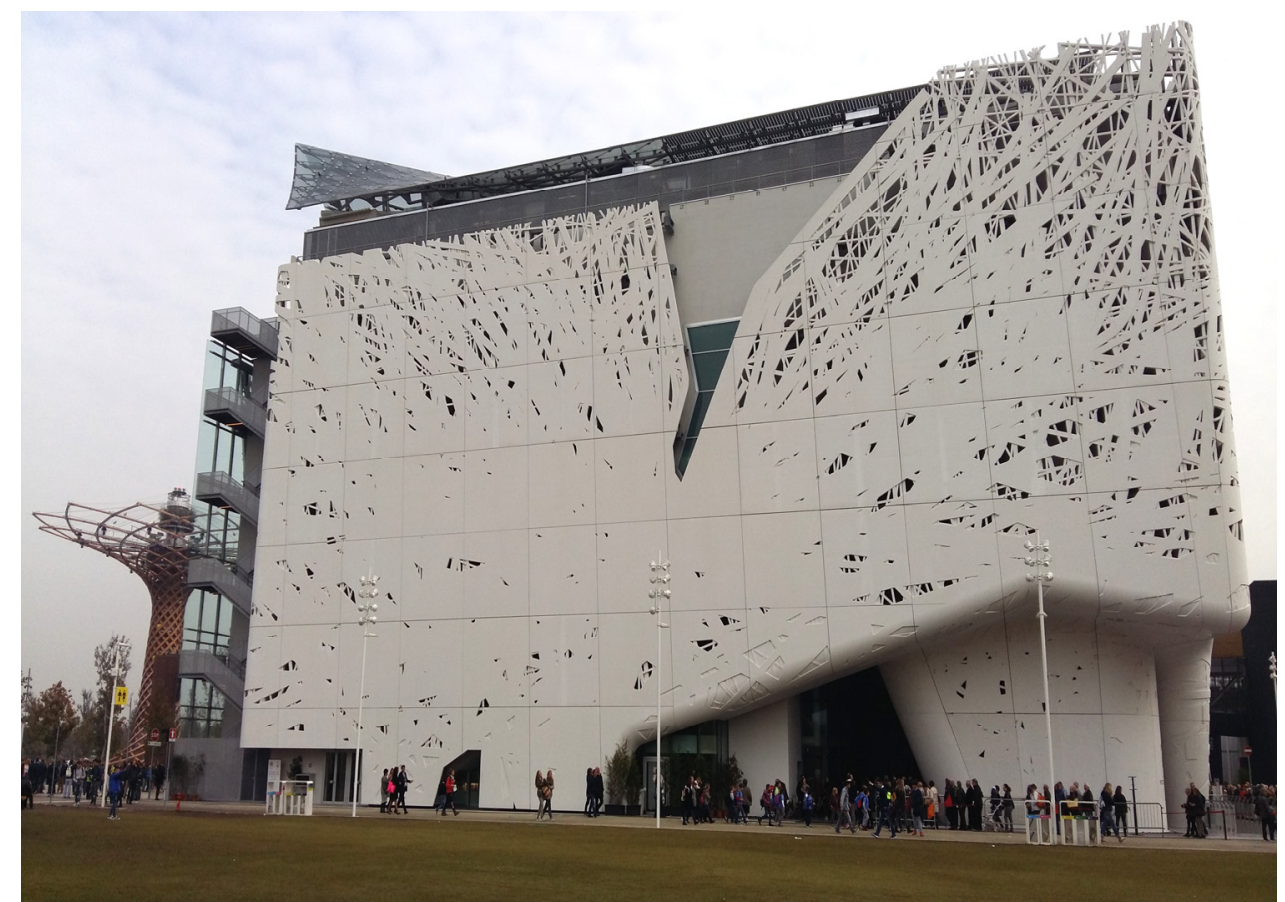

Fig. 8 Palazzo Italia—in the Padiglione Italia, project of Arch. M. Molè and Arch. S. Tradati, Rho-Pero, Milan Expo S.p.A., 2015.

Source: photo by the author: Mocerino, C. on October 26, 2015.

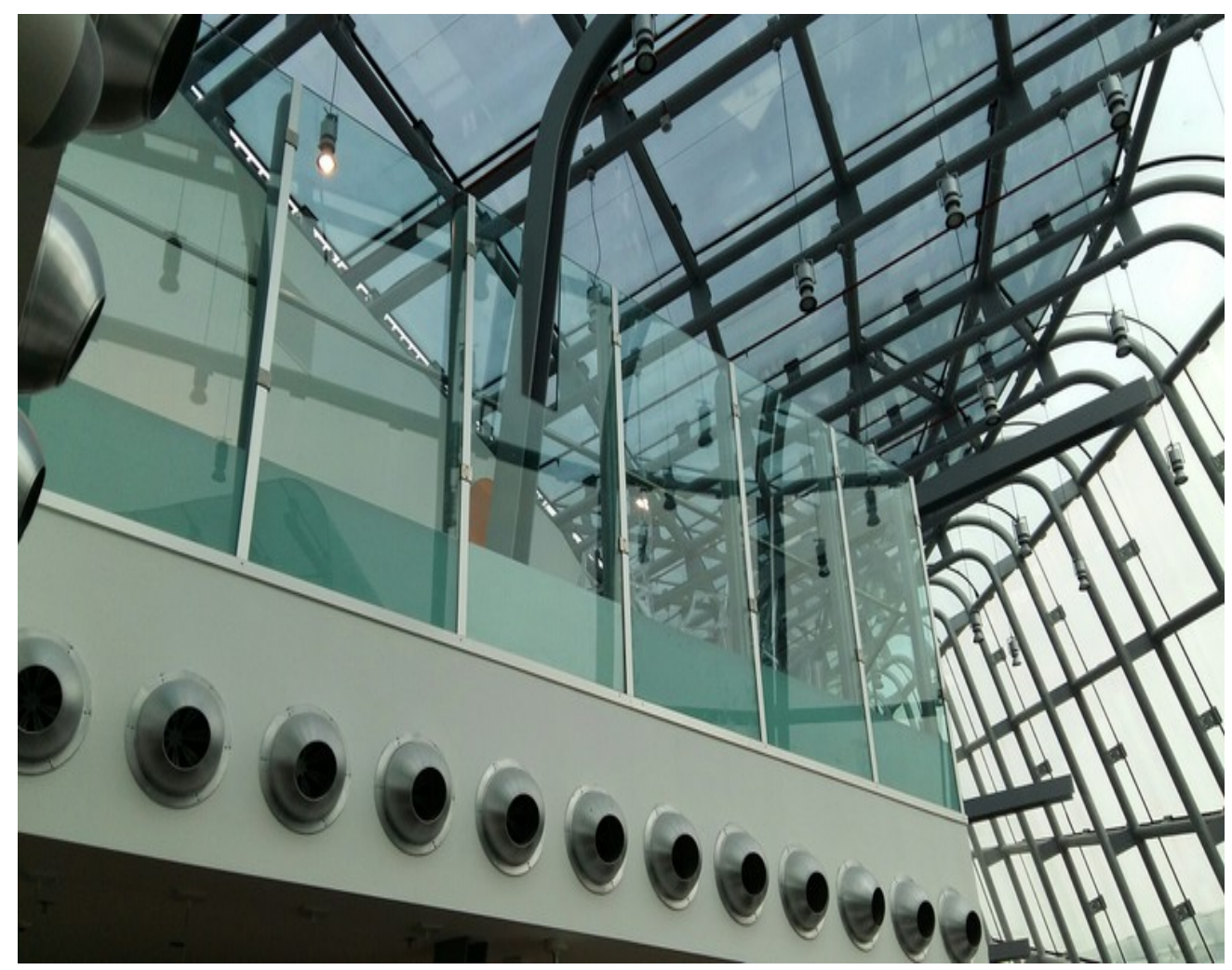

Fig. 9 Palazzo Italia, restaurants space, photovoltaic glass roof.

Source: photo by the author: Mocerino, C. on October 26, 2015. 


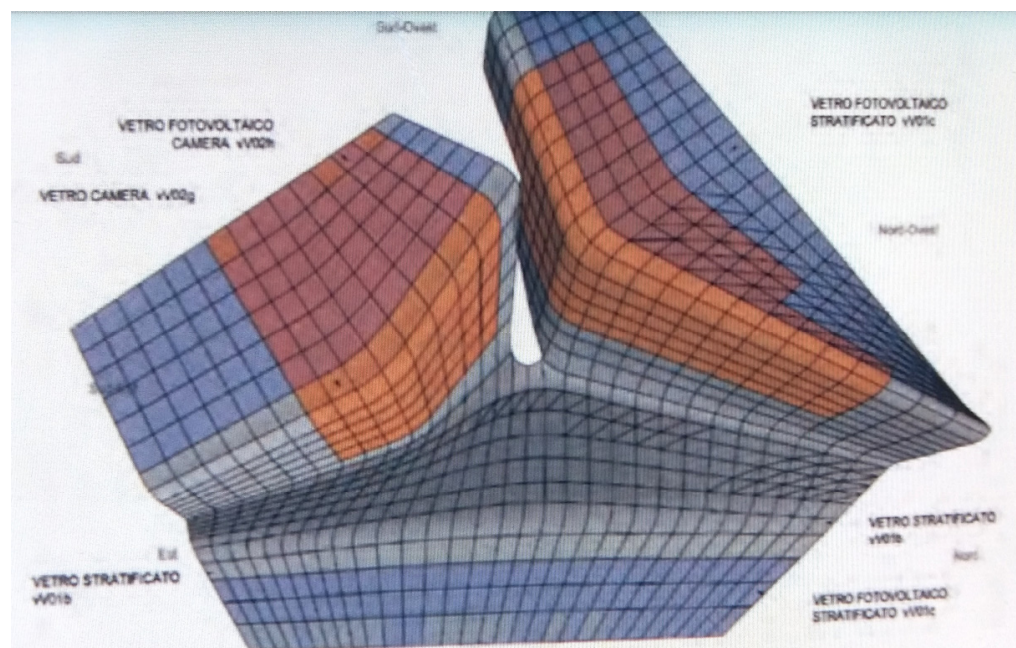

Fig. 10 Palazzo Italia, glass and photovoltaic roof. CFD modeling for fluid dynamics testing.

Source: Ref. [20].

interconnected with the distribution blocks up to the level of the dining floor $(8 \mathrm{~m} \mathrm{high})$, including the upper mezzanine floor (Fig. 9), and whose fruition transmits the rapid spatial perception of the architectural work. To the west, an overhanging wall was built for functional and usable needs. On the 4th floor stands the delegation room, with a top floor for a winter garden, overlaid by the sail cover, with a supporting structure of a painted steel grid.

\subsection{Sustainable Principles and nZEB Systems}

\subsubsection{Coverage}

According to passive bioclimatic principles, the "sail" roof cools the air through natural ventilation by reducing the foyer's internal temperature during summer times by about $3{ }^{\circ} \mathrm{C}$. Fluid dynamics testing has been developed through a CFD (computational fluid dynamics) model (Fig. 10) simulating airflow characteristics and temperature values for user comfort and safety. In general, this kind of analysis has as well indicators surface building temperatures, HVAC air conditioning systems and heat sources. The glass cover is made of a three-dimensional spatial grid structure of calendered beams. The steel and glass envelope has a main wrap warrant, with support for twin spaced beams, with double circular tubular profiles (Ø170 $\mathrm{mm}$ and $18 \mathrm{~mm}$ thick), steel $\mathrm{S} 355 \mathrm{~J} 2 \mathrm{H}$, connected by shapes with shaped vertical linking plates. Instead, the transversal secondary warp is made of single tubular circular sections and is connected by welded/bolted hidden joints to the main body. The cover, designed with BIM technology, was impregnated (Fig. 11), covering the underlying foyer and weighing about 400 tons. The modules, which complete the $4,000 \mathrm{~m}^{2}$ on a three-dimensional model (Fig. 9), like the entire building, are flat and curved with glasses of different types. In fact, in the flat sail roof grid, laminated layered photovoltaic glass sheets have been applied, BIPV (building integrated photovoltaic), according to UNI 7697, custom product and high performance, extraordinary heat $(20 \mathrm{~mm}$ total thickness). It is thermally treated with $12 \mathrm{~mm}$ tempered HST (heat soak test) $+0.76 \mathrm{~mm} \mathrm{PVB}$ (polivinylbutyral), a plastic film that provides excellent alkali resistance at high temperatures and is an excellent anti-mold, $+10 \mathrm{~mm}$ hardened. High energy efficiency is achieved through the integration of up to 96 polycrystalline photovoltaic cells $(156 \mathrm{~mm}$ $\times 156 \mathrm{~mm}$ ) in these glass layers for a maximum power of $490 \mathrm{WP} /$ module. The roof produces altogether $70 \%$ of the energy requirements of the building with about $150 \mathrm{kWp}$ of energy and glasses CEI EN 61215 and CEI EN 61730. In the same glass cover, made by Staulbau Pichler, and below the photovoltaic area, 


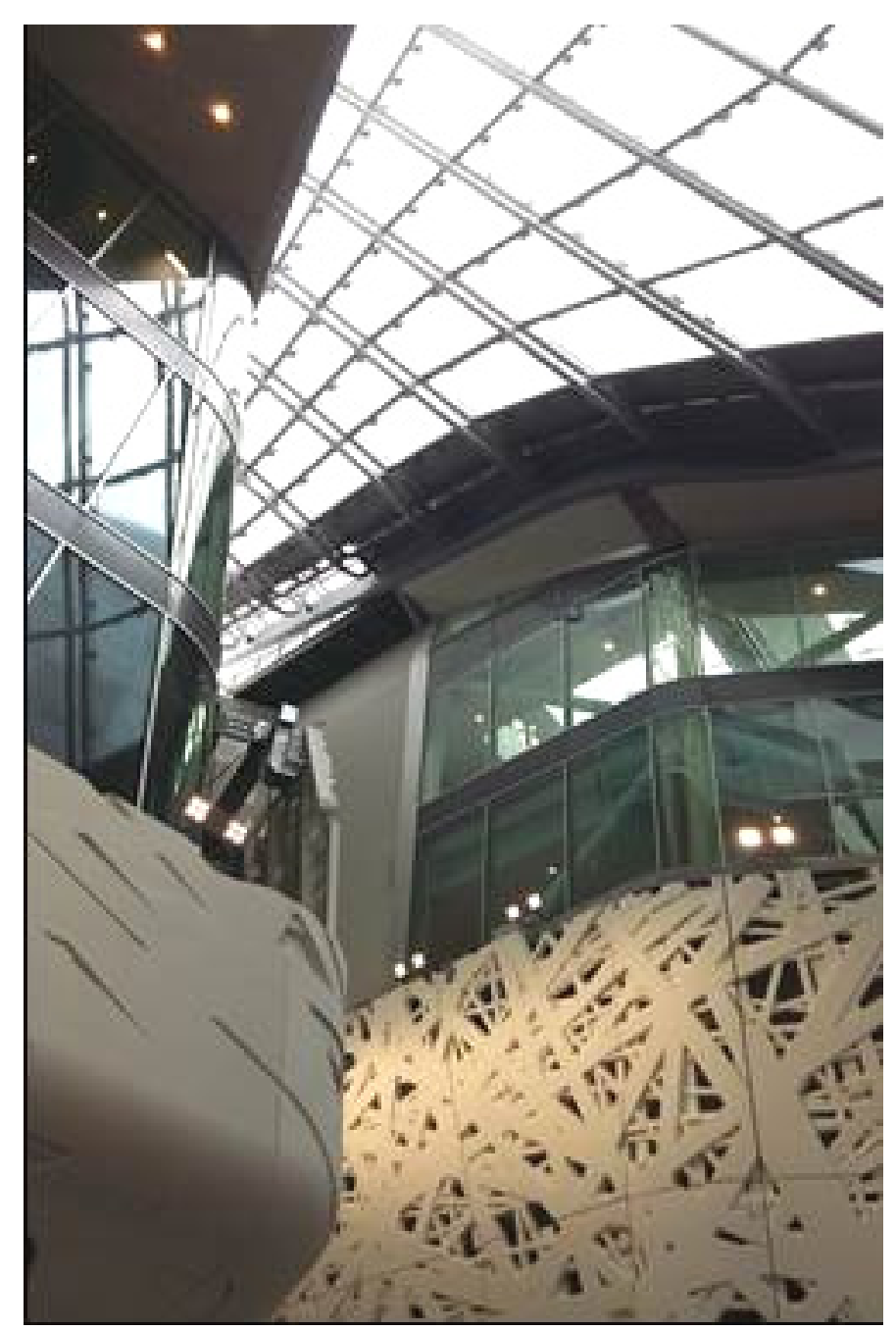

Fig. 11 Palazzo Italia, foyer, roof detail and fiber cement panels.

Source: photo by the author: Mocerino, C. on October 26, 2015.

there are types of flat modules, with solar control glass and laminated glass connected to the steel structure, through the suspension system of round passers or spherical custom bolts. They are realized in Aisi 316 steel, fixed to the tubular profiles via rockers. The glass modules are sealed with silicone.

The vertical section of the sail is made of a continuous facade system, with uprights and extruded aluminum crosspieces, thermal cut. Wastewater recycling is carried out, from the hallway sail for non-drinking use.

\subsubsection{Facades}

In the technological system, partial transparent closures of continuous facades have a transmittance of direct solar energy, of $\mathrm{Uv}<1.3 \mathrm{~W} / \mathrm{m}^{2} \mathrm{~K}$ and $\mathrm{Uv}=0.30$ $\mathrm{W} / \mathrm{m}^{2} \mathrm{~K}$, relative to those without solar shielding. The Gualini Spa's high-rise continue facades, are systems of windows with selective glassware, with solar control and high-temperature thermal insulation.

Instead, on low floors, the facades are with double emissive low glasses, such as those in the Hall.

For the continuous facades, the Schüco FW 50+ system with high thermal performance and load capacities up to $700 \mathrm{~kg}$ per side, was developed with BIM modeling, mainly with the structure and design components. The aluminum doors are of the Schüco ADS HD (heavy duty) system with requirements and performance specifications, including resistance and 
fire and intrusion, transitability, geometric control, regularity of finishes, etc. On the north and east facades and in the hall are distinguished metallic reticular structures, some of which are inclined inside.

Other high thermal insulation enclosures are opaque acrylic facades, while a white branched design made by Italcementi Spa, with Styl-Comp construction technology, of fiber cement photocatalytic panels assembled and anchored to the closures, is the ventilated wall of the sustainable architectural envelope (about $9,000 \mathrm{~m}^{2}$ ). This is crossed by natural micro-ventilation flows that assure, in the interior, thermo-hygrometric conditions of the environments. It is implemented by a transverse branched skin, with the dual solar shading function, whose layer drilling increases, extending from the ground level, from percentages of $20 \%, 40 \%$, up to $70 \%$ of the last floor. On the façade prevails the white color of self-cleaning concrete layers based on the principle of $\mathrm{X}$-active antismog. This material (used for the first time for the construction of the three pre-fabricated sails of the Dives Misericordia church in Rome-Arch. Richard Meier) in contact with light, transforms the air pollutants into inert salts with the elimination of particles of $\mathrm{CO}_{2}$. For architectural and air-conditioning requirements, there are about 900 different panels with their respective supporting armor, with molding systems (synthetic resins) of "negative" and "positive" molds in steel castings, with jet and injection of nanostructured material biodynamic, i.activebiodynamic. It is made up of $80 \%$ mortars, recycled (a mix of Carrara white marble scrap powders), forming a type of cement with high resistance (compression and flexion) characteristics, with features versatility, durability and fluidity, giving dynamism to the envelope and triple plasticity, compared to standard cement. For the installation of concrete panels (4-layer three-dimensional-4.00 mx $4.00 \mathrm{~m}$ ), a first supporting structure, anchored to the walls of the building, consists of metal shelves with a C-profile and a box-like linear and continuous. To this latter, the metal brackets of hot-dip galvanized steel (adjustable along three reference axis Cartesian axes) are fixed to the anchoring of the panels. For architectural and air-conditioning requirements, each module is individually assembled with a dry, mortarless system throughout the building envelope (Fig. 12), from opaque closures to transparent ones to structures steel wire mesh.

In addition, on the same shelves anchored to the architectural work, the grill of the Keller type is bolted, which constitutes the maintenance catwalk. Breathable skin becomes, in addition to a component, an efficient technological solution, highlighting high performance requirements for solar radiation reduction (about 70\%), such as darkening on glass walls, north/east and south/east, and energy containment, on parts of opaque facades, to north/west and south/west.

\subsubsection{Energy Systems}

For HVAV air conditioning systems, the VMC (controlled mechanical ventilation) has been installed with UTA (air treatment unit) with temperature, air quality and humidity control. Provided with UNI 10339 air conditioning units VRF/VAV (variant refrigerant flow/variable air volume), and inverters, they are installed in the technical areas of the roof and the basement where the sprinkler water and fire extinguishers locate. From the reception, from the ground floor to the exhibition space, with 4th floor delegation room, including the 3rd floor, three UTAs are installed, with mandates of $8,200 \mathrm{~m}^{3} / \mathrm{h}, 40,000$ $\mathrm{m}^{3} / \mathrm{h}$ and $10,600 \mathrm{~m}^{3} / \mathrm{h}$. While a UTA for auditorium and multifunctional spaces, respectively, $10,500 \mathrm{~m}^{3} / \mathrm{h}$ and $10,000 \mathrm{~m}^{3} / \mathrm{h}$, two UTAs are in the kitchen and restaurant rooms equipped with hood and extractor. Heat pumps with heat pumps are of polyvalent type of groundwater $\left(15^{\circ} \mathrm{C}\right)$, for simultaneous production of thermoconductor fluids, returned at $9{ }^{\circ} \mathrm{C}$ in winter and $26{ }^{\circ} \mathrm{C}$ in summer. Electric pumps through inverter systems pressurize the hydronic circuits and, with the use of groundwater, reach a maximum power of about 


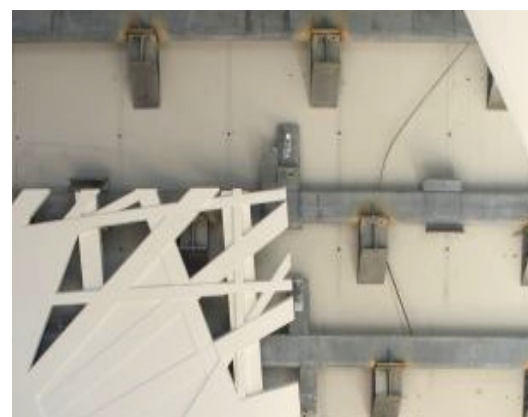

(a)

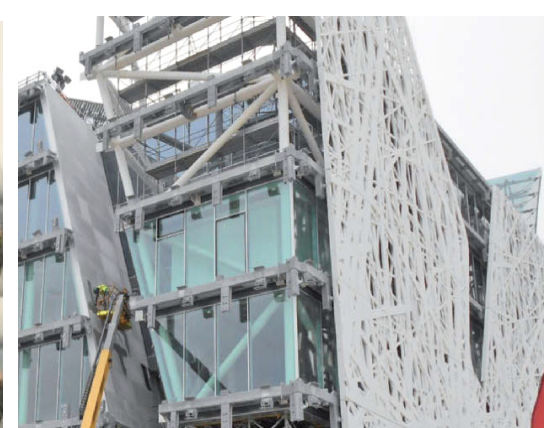

(b)

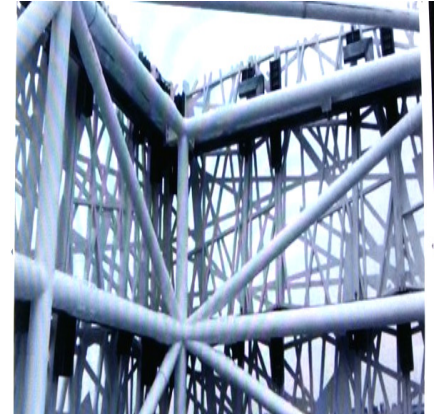

(c)

Fig. 12 Ventilated wall, fiber cement panel anchoring systems, on continuous iron girders: (a) opaque wall in c.a.; (b) continuous glass facade; (c) tubular sections with circular steel section.

Source: Ref. [21] for Figs. 12a and 12b; Ref. [20] for Fig. 12c.

$1,102.7 \mathrm{kWf}$ in the summer and $721.3 \mathrm{kWf}$ in winter, compared to the $791 \mathrm{kWf}$ peak of the total energy requirement. Then, high efficiency systems such as outdoor air-cooling, inverter technology for variable-speed plug-in fans, $\mathrm{CO}_{2}$ probes to adjust the ventilation air flow rate (according to attendance and heat demand). The maximum speed is $7 \mathrm{~m} / \mathrm{s}$. Renewable source is a geothermal power plant with low and constant temperatures throughout the year. Air extractors with grids, ceiling or walls are installed in the rooms, while ventilation valves are installed in the countertops of the sanitary facilities. For the ventilation of the offices, the SagiCofim Concretcool system was installed in ceilings, without ceilings, equipped with linear loudspeakers installed on the walls and modular pipes $(\varnothing 80 \mathrm{~mm})$ made of aluminum extruded, iron of the slabs in c.a. (reinforced concrete) and cast in work. The air flow from the UTA [22] circulating in the coils $\left(12{ }^{\circ} \mathrm{C}\right.$ in the summer, $21{ }^{\circ} \mathrm{C}$ in the winter), using the heat-generating principle of the mass of the building, surrenders its refrigerating energy. This system, together with the radiant floor system, achieves a saving of about $40 \%$ of the energy for air conditioning. An enforced antifouling (DM09/05/2007) and SEFFC (evacuation of smoke and heat evacuation) system has been installed, with at least a free UNI antismoking of $2.00 \mathrm{~m}$, which is integrated using some of the same HVAC system. For this system, dynamic patterns of smoke flows have been elaborated, which have defined certain parameters of the characteristics, dimensions and portions of the forced systems to be adopted with related systems, with the division of propagation into macrozones. An intelligent EMS (energy management system) with KNX protocol (Siemens Konnex) manages installations including $270 \mathrm{~kW} / 135 \mathrm{kWh}$ storage (for power flow optimization) along with connection, photovoltaic, functional lighting and processing air, with 29 loads control and monitoring of 59 loads/BT lines. Led lighting systems have been adopted in the various indoor and outdoor environments of the building, including special wall washer projectors $(120 \mathrm{~W})$ at 9-12 $\mathrm{m}$ in the lobby. According to EPBD (Energy Performance of Buildings Directive) European Directives (L.90/2013), this building is considered an NZB (almost Zero Energy Building). It was ranked in energy class A and awarded the PCI Excellence in Design Awards 2016 for Best International Building Structure.

\section{Conclusions}

New constructive practices are developed according to advanced projects integrated with IPD and virtual 3D modeling with the computational designer. They adopt, in accordance with the policy of digitization policy and the European Union Public Procurement Directive of 2014/24, BIM technology, as a 
management control instrument incorporating efficient systems and advanced technologies, innovative and engineered materials. So the goals are aimed at new digitized sustainable projects, through an interoperable, interdisciplinary construction process. It involves specific competencies including designers and companies with the participation of the clients. In particular, the BIM manager, the BIM coordinator, the BIM modeler, are here for the digital management of the various processes and where the instrumentation is capable of managing all stages of a building's life cycle, thus, flexible and coordinated management in the construction of low-impact architectural dynamic envelopes (EPBD-L.90/2013), with renewable energy sources. New performance of flexibility, durability, dynamism and safety at static level, points out the RBEs of the technology system, and accumulation and energy systems from renewable sources. The methodologies are based on the use of BIM technologies, with integration of active and passive systems and high performance components, adaptive and natural materials and products that improve efficiency and effectiveness in construction.

So new world strategies, a third economic revolution, with the digitization of ICT sector, in the building, are adopted, and new management and infrastructural building models, with regeneration of built and of the new constructions, are developed.

The challenge is to improve the quality of user life and environmental sustainability in urban and territorial spaces. In fact, buildings become more sustainable and intelligent, with adaptive, dynamic and interactive architectural envelopes, which filter with the outside environment transform solar energy from renewable sources into electricity.

So we aim at interoperability in the AEC and in new economy by the parametric design of BIM and the application of building automation systems. At last, we also need to strengthen self-management and control capabilities, by the application of high performance robotic technologies and by the efficiency and effectiveness of all constructive and technological systems.

\section{References}

[1] Tronconi, O. 2015. Le Nuove Forme Dell'Abitare 2.0. Santarcangelo di Romagna (RN): Maggioli Editore. (in Italian)

[2] Rifkin, J. 2012. La Terza Rivoluzione Industriale. Come il "Potere Laterale" sta Trasformando l'Energia, l'Economia e il Mondo. Milan: Ed. Mondadori-Oscar Bestsellers. (in Italian)

[3] Texas A\&M University Construction Science Department. 2016. 2016 Construction Technology Report. Accessed March 2, 2017. http://jbknowledge.com/wp-content/ uploads/2016/12/JBK_Construction_Technology_Report 2016.pdf.

[4] European Commissions. 2016. New Digital Technologies for Construction and Their Impact on Contractual Relationships. Accessed February 5, 2017. http://www.eic-federation.eu/media/uploads/ga_berlin_20 16/9_dg_grow_koeppen_eic_2016.pdf.

[5] KPMG. 2016. Building a Technology Advantage - KPMG. $\begin{array}{llll}\text { Accessed } & \text { March } & 2017\end{array}$ https://assets.kpmg.com/content/dam/kpmg/xx/pdf/2016/ 09/global-construction-survey-2016.pdf.

[6] Himmelb, C. 2016. "MOCAPE Cultural Complex in Shenzhen (China).” Accessed March 3, 2017 http://www. arquitecturaviva.com/Info/News/Details/9512.

[7] Himmelb, C., Prix, W. D., and Partner ZT GmbH. 2015. "We Start the Future of Construction." Accessed April 4, 2017. https://www.youtube.com/watch?v=R64IEixoYJ0.

[8] Zeljic, A. S. 2010. "Shanghai Tower Façade Design Process.” Accessed February 2, 2017. http://www.gensler.com/uploads/documents/Shanghai_T ower_Facade_Design_Process_11_10_2011.pdf.

[9] Winey, D. 2012. "Shanghai Tower: The Curtain Wall." Accessed January 2017. https://www.gensleron.com/cities/2012/11/27/shanghai-to wer-the-curtain-wall.html.

[10] Eastman, C., Teicholz, P., Sacks, R., and Liston, K. 2016. Il BIM. Guida Completa al Building Modeling Information. Milan: Ed. Hoepli. (in Italian)

[11] Kiefer. 2013. Concrete Core Cooling with Air CONCRETCOOL. Accessed March 9, 2017. http://www.kieferklima.de/uploads/tx_userkidownloads/ Brochure_Concretcool.pdf.

[12] Kiefer. 2015. CONCRETCOOL. Accessed March 9,2017. http://www.kieferklima.de/uploads/tx_userkidownloads/ Detailzeichnungen_CONCRETCOOL-EN.pdf.

[13] MPA The Concrete Centre. 2017. Concrete Floor 
Solutions for Passive and Active Cooling. London: Publisher MPA The Concrete Centre. Accessed April 12, 2017. http://www.concretecentre.com/PublicationsSoftware/Publications/Concrete-Floor-Solutions-for-Passi ve-and-Active-Co.aspx.

[14] Paris, T. 2017. Design. Testi e Contesti. Macerata: Ed. Quodlibet. (in Italian)

[15] Boeri, A., Cinti, S., and Conato, F. 2015. Elementi Costruttivi. Progetto e Realizzazione. Bologne: Ed. Pitagora Bologna. (in Italian)

[16] Materia. n.d. Earthquake-Resistant Bridge Thanks to New Flexible Materials. Accessed March 2, 2017 https://materia.nl/article/earthquake-resistant-bridge-flexi ble-materials/earthquake-resistant-bridge-thanks-to-new-f lexible-materials/.

[17] Mocerino, C. 2015. "Modello Edilizio nell' Innovazione di Processo Progettuale per il Recupero e la Riqualificazione Dell'Edilizia Terziaria. Linee Guida Prestazionali.” Ph.D. thesis, Sapienza University of Rome.
Accessed September $\quad 10, \quad 2016$. http://padis.uniroma1.it/handle/ 10805/2766. File: Tesi DdR. C.Mocerino XXVI ciclo.pdf. (in Italian)

[18] Fox, M. 2016. Interactive Architecture: Adaptive World. Los Angeles, CA: Ed. Fox.

[19] Nemesi \& Partners. 2015. Padiglione Italia Expo Milano 2015. Accessed February 12, 2017. http://www.nemesistudio.it/it/progetti/tipologia/culture/it em/1151-padiglione-italia-expo-milano-2015.html.

[20] Alacero. 2016. Tutto l'acciaio di EXPO 2015. Accessed April 19, 2017. http://www.alacero.org/sites/default/files/ u16/bt_16-02_n07.pdf. (in Italian)

[21] Colombo, C. 2015. Expo Milano 2015. Padiglione Italia. Accessed April 3, 2017. http://www.ilnuovocantiere.it/files/2015/05/Il-Nuovo-Ca ntiere-aprile-2015.pdf.

[22] Stefanutti, L., and Pedrini, L. 2014. "Sistema Concretecool per la Climatizzazione." AiCARR JOURNAL, 26 a.5-June 2014. Ed. Quine srl. (in Italian) 